\title{
Forum
}

\section{Generational conflict, consumption and the ageing welfare state in the United Kingdom}

\author{
PAUL HIGGS* and GHRIS GILLEARD*
}

\begin{abstract}
The British welfare state is over 60 years old. Those who were born, grew up and who are now growing old within its ambit are a distinctive generation. They have enjoyed healthier childhoods with better education than previous populations living in Britain. That they have done well under the welfare state is accepted, but some critics have argued that these advantages are at the expense of younger cohorts. The very success of this 'welfare generation' is perceived as undermining the future viability of the welfare state, and some argue that the current levels of income and wealth enjoyed by older cohorts can only be sustained by cutbacks in entitlements for younger cohorts. This will lead to a growing 'generational fracture' over welfare policy. This paper challenges this position, arguing that both younger and older groups find themselves working out their circumstances in conditions determined more by the contingencies of the market than by social policy.
\end{abstract}

KEY WORDS - welfare state, generational conflict, consumer, contingency.

\section{Introduction}

One of the most notable features of the recent financial crisis has been the resurrection of the theme of intergenerational conflict as a major fault line in modern welfare states (Esping-Andersen 2009; Willetts 20I0). While never entirely absent from policy debate, the renewed focus on generation is framed around issues of perceived fairness in the distribution of welfare resources in an era of individualised welfare. While the concept of generation is contested, it has become more resonant as those cohorts associated with the 'baby booms' and 'baby bulges' of the mid-2oth century move into retirement (Gilleard and Higgs 2005). In the United Kingdom (UK), the cohorts that grew up after the Second World War have not only benefited

* Division of Research Strategy, University College London, UK. 
from the expansion of educational opportunities and relatively stable employment opportunities, but also experienced higher levels of income and material comfort than their predecessors (Harkin and Huber 2004). For the cohorts following behind, the world looks more unfriendly; so unfriendly, in fact, that some commentators have argued that the advantages of present-day retirees can only be sustained at the expense of younger cohorts whose education, employment and social rights are being restricted as welfare states reform, retrench and become less redistributive.

As a consequence, a line of thought has emerged that sees the 'welfare generation' undermining the long-term viability of the various forms of welfare state (see Williamson, MacNamara and Howling 2003 for an overview for the United States of America (USA), and Chauvel 2006 and Esping-Andersen 2002 for Europe). The maintenance of current levels of income and wealth for older cohorts, it is claimed, can only be sustained by increased cutbacks for younger cohorts, for whom 'welfare' means labour-market 'activation', while work becomes a much more contingent experience mediated through individualised contracts between employer and employee rather than through collective social institutions (Walker and Wiseman 2003).

In the UK, the main focus of this paper, those cohorts currently entering retirement are seen to enjoy similar levels of participation in consumer society as those of working-age adults (Higgs et al. 2009) without being subject to the insecurity that seems to limit the prospects of those born after them (Kuhnle 1999). The tension is apparent. The capacity of 'baby boomers' to enjoy the benefits and security of a welfare-state society seems to be in an inverse relationship to younger cohorts' experience of contemporary welfare arrangements. This appears to confirm many of the prognoses made by such pioneering commentators as David Thomson (I989) and Samuel Preston (I984) who predicted growing intergenerational conflict a quarter of a century ago. While such conclusions resonate even more strongly now, we would argue that the reality is more complex and revolves around both definitional issues, such as the nature of a 'generation', and the significance of social policy debates in determining social relationships.

By identifying the conflict over welfare resources as a key area of contestation between generations, there is a risk of valorising social-policy debates over broader economic processes. We suggest that the 'generational habitus' of the present-day cohort of older people has been shaped by consumption practices that ran in tandem with the benefits of the 'Golden Age' of welfare and its concomitant mass affluence (Taylor-Gooby 2004). This older cohort's continuing engagement with consumption is as pronounced as that shown by younger cohorts in the working ages (Jones et al. 
2008). Through this common engagement with the market, the older generation shares the insecurity and contingency that mark out the lives of those born in later decades. While younger cohorts may be more open to the dispositions necessary for life in what Bauman (2007) has called 'liquid modernity', despite not enjoying the built-up benefits of the ' golden' or even 'silver' ages of welfare, we suggest that the continuities of consumerism will outweigh any differences in the experience of welfare. Consequently, we contend that anticipated differences in future welfare entitlements are unlikely to become lines of generational fracture. The very contingency of contemporary life and the individualisation that 'is imposed on the individual by modern institutions' (Beck 2007: 68I) affect the savings, property values and individual entitlements of all cohorts. A common consumerist habitus links rather than separates successive post-war birth cohorts, and is sustained by considerable intergenerational transfers of both cash and care (Kohli I999; Kohli and Albertini 2009). We conclude that the role of differential generational welfare arrangements in creating social conflict has been overplayed. Retirees and people of working age alike find themselves organising their lives in conditions determined more by the vagaries of markets than by social policy.

\section{Generation and generational conflict}

Mannheim (1997) introduced the idea that a birth cohort forms a distinct generational unit when its members become conscious of their role in carrying moments of significant social change. A key element in Mannheim's conception of a generational unit is the consciousness of a divide or split in the experience and outlook of one cohort from those of earlier cohorts. This interpretation of generational conflict differs from the more traditional generational conflict associated with clashes between parents and their adult children. Distinctive forms of such Mannheimian generational conflict appeared twice during the 2oth century - during the I920s and the I960s. But while the earlier conflict was largely confined to society's elites, that of the 'long ig6os' spread across all classes to become part of a new 'mass culture' (Gilleard and Higgs 2005). The sources of generational division were expressed through culture - in fashion, music, the media and leisure - and social outlook, and were in both cases facilitated by rapid economic and technological change. The economic and technological changes that gathered pace after the Second World War had impacts for most strata in society, were sustained for much longer, and resulted in the rise of mass consumerism, mass culture and mass affluence. 
While some of the most visible British icons of the ig6os' 'cultural revolution' were born in the I940s - John Lennon and Paul McCartney (musicians), George Best and Bobby Moore (footballers), and Jean Shrimpton and Twiggy (models) - many of those who fashioned the ig6os' culture were born during the I93os or earlier (e.g. artists such as Peter Blake and Bridget Riley, designers such as Mary Quant and Terence Conran, and music producers and promoters such as Brian Epstein and Micky Most). Those seen by these 'children of the revolution' as the old generation were mostly contemporaries of their own parents, born during the first three decades of the 2oth century whose adult lives were fashioned by the hard times of the ig3os and I940s.

Members of this earlier cohort had much less experience of intergenerational conflict. Social mobility during the first half of the 2oth century was limited (Heath and Payne I999); the grandparents of those born in the I940s shared many of the same experiences as their children - long hours of work, large-scale industrial labour, social and geographical proximity between home and work, a clear household division between men and women, and shared multi-generational households (particularly for the youngest parents). By contrast, the social mobility of those reaching adulthood during the long ig6os was considerably greater, of a degree not seen before or since (Goldthorpe and Mills 2008). These changes in work and employment opportunities increased the cultural distance between the generations, but the welfare benefits that accrued to the cohort born in the I940s were not resented by their parents - indeed they were welcomed. The differential outcomes of the two generations - one born of sacrifice, the other reaping the benefits of that sacrifice - did not lead to a criticism of the new welfare policy nor did it make the older generation envious or resentful of the fortunes of the younger cohort.

Such expectations of progressive advancement for subsequent generations have been confounded. The children of the I940s' birth cohort have experienced greater job insecurity and more poverty than their parents, shifting the direction of 'intergenerational' inequity to favour older rather than younger adults (Albertini, Kohli and Vogel 2007). The Ig8os seem to have been the point of flip-over. Older people began leaving the workforce in increasing numbers and at earlier ages (Costa I998). Although this was perceived by some at the time as an 'age discriminatory social process designed to exclude older people en masse from the workforce' (Walker 1990: 59, cited in Laczko and Phillipson I991:4), many of those taking retirement were doing so under conditions remarkably better than previous generations. Poverty rates amongst the over-sixties declined, as poverty rates amongst younger households rose. By the turn of the century, the evidence was clear - the profound inequality of age was becoming history. 
UK pension income, in the form of public old-age pensions, occupational pensions and private pensions, was establishing a position of financial security for the majority of pensioners (Gilleard and Higgs 2005: Figure I.I).

At the same time, public concern was being raised over the sustainability of this 'equalisation' of the lifecourse. By the I99os, a new framing of intergenerational conflict was being propounded-not one formed within the framework of culture or social relationships but by governmental and global economic policy advisors. This purported conflict was based not on a new generational consciousness that was realised in the cultural or social distance between parents and their adolescent/adult children as was the case during the 'long' ig6os, but through new concerns over the sustainability of 'pay-as-you-go' pension schemes (Disney I996; World Bank I994). This in turn led to the re-framing of the 'intergenerational crisis' as an international financial policy issue.

\section{The fiscal framing of the intergenerational crisis}

Some of the origins of the generational equity debate stem from the debates surrounding the 1983 amendments to the United States Social Security programme. These debates drew upon images of intergenerational inequity, typified by an article in Forbes magazine which had the charged title 'Consuming our Children' (Chakravarty and Weisman i988). The debates led to demands that more attention be given to the issue of 'generational justice' in order that 'the net tax burden of paying for government purchases is spread equitably across living and future generations' (Gokhale and Kotlikoff 1999: 76). Behind the argument lay a general assumption that generational justice could be achieved only through cuts in current benefits - and particularly social security payments to older people. This line of argument was subsequently extended to the international arena, when Kotlikoff and his associates produced a report titled Generational Accounting Around the World (Auerbach, Kotlikoff and Leibfritz i999).

The success of this framing was further demonstated when the World Bank published Averting the Old Age Crisis, which asserted that conventional 'pay-go' pension schemes inevitably created a situation where gains for one generation occur at the expense of another (World Bank 1994: 325). In the context of increasing longevity and growing affluence, the report not only advocated a shift to greater individualisation of pension arrangements, but also the adoption of intergenerational accounting. Significantly, a similar concern with intergenerational equity emerged in the debates surrounding the future of the European welfare state brought together by Esping-Andersen (2002), which included a serious discussion of Musgrave's 


\section{$\mathrm{I} 444$}

idea of the need to maintain a fixed ratio of contributions and benefits between generations (Musgrave ig86). ${ }^{1}$

We dispute, however, the idea that generational equity can be an organising principle for social security in later life. These issues are more influenced by the current practicalities of social policy and party political advantage than they are about ideals or accounting principles. Consequently, while the long-term ambition of social policy theorists of both Right and Left might be to usher in a more rational and generation-aware environment for pensions, the collapse of what Giddens (1994) has described as the 'cybernetic model' of state-directed planning has led to the emergence of an increasingly unpredictable financial system on which much later-life income depends. ${ }^{2}$ If the fact that many of these policies would take decades to mature is added to the mix, then the idea of generational equity, or of the inverse, generational conflict, operates more as a trope than as a useful tool for analysis.

\section{Cross-generational consumer citizenship?}

The retrenchment of the welfare state and the expansion of identity politics in health and welfare have run alongside the expansion of consumerism and the emergence of the consumerist voice within social policy as connected developments ( $c f$. Annetts et al. 2009). Alongside the material improvements in the health and wellbeing of older people, these have combined to make 'active ageing' a dominant paradigm for health and social policy (Walker 2002, 2009; World Health Organisation 2002). In so doing, it has allowed the culture of consumerism to penetrate the welfare arena. 'Active ageing', with its emphases upon autonomy, choice and consumer rights, reflects processes that privilege agency, autonomy, individualisation and personal responsibility, while underscoring the need to limit collective provision to those who are least able to look after themselves (Moffat and Higgs 2007). Such people are also the least able cognitively and physically to represent themselves as other than structurally dependent, but they are still capable of being incorporated despite their lack of a clear voice-individual or otherwise. Other entities have emerged to advocate and act on their collective behalf, retaining the idea of agency through the practice of proxy consumer advocacy and the politics of identity (Gilleard and Higgs 2009).

Health and social policies in the UK are now expected to deliver care in a more individualised and commodified form than was the case during the early development of the welfare state. This change in discourse reflects as much as it shapes contemporary culture. At the same time, it creates new 
tensions, not least between the desire to support individual decision-making and the need to target collective resources effectively. In November 2007, the Commission for Social Care Inspection (CSCI) found that 73 per cent of local authorities were planning to refuse care to everyone whose needs were not considered to be 'substantial' (Carvel 2007). In December of the same year, the UK government announced plans to transform the organisation of social care in England and Wales (Department of Health 2007), giving direct control to older people over how and where money will be spent through the introduction of personal budgets for adult social care. While these proposals turn social care into a consumer expenditure item, and as eligibility criteria are shifted further toward those in greatest need, the gap widens between the rhetoric of choice and the reality of need. Those most entitled to purchase their own care will be least able to go 'shopping' - whatever the nature of goods and services on offer (Gilleard and Higgs I998).

We argue that the third age is a 'cultural field' that at least in Europe has been made possible by the post-war welfare state (Gilleard and Higgs 2005). It was not created by welfare ideology, however, but rather the field has been formed by the consumerist values of choice, autonomy, selfexpression and pleasure - values of the I96os, not the I930s and I940s. A welfare state that was constructed out of necessity has since been reformulated to engage with, not undermine, these new rules. This change is realised more completely in the lives of young adults, who have grown up under conditions of increasing commodification and decreasing institutionalisation (Beck 2007). Subject to the market more than ever, and supported and encouraged by the state and corporations to participate more effectively as individual consumers, the circumstances of those born after the I970s have been less collectively organised than those who are now participants in 'the third age'. The traditional structures of labour markets and occupational hierarchies have become more fluid, with innumerable and diverse previously-unimagined occupations coming into existence, while millions of 'traditional' jobs have disappeared (Strangleman 2007). Unlike the old jobs, those in 'the brave new world of work' have more tenuous connections to the conventional ways that money was made (Beck 2000). Jobs are more individualised and less likely to generate a guaranteed level of income in retirement. Opportunities for unexpected wealth and high incomes are balanced by sudden lay offs, restructuring and general economic uncertainty (Ransome 2005).

In a similar fashion, personal relationships have become less predictable, the ties of kinship have become more complicated, and the social importance of marriage has become less determinant (Zinn 2004). Technological developments, such as mobile phones and the internet, 
have transformed the nature of communication between individuals and led to the profusion of more intense virtual forms of community (Gilleard, Hyde and Higgs 2007). Housing tenure and the patterns of people's living arrangements have been radically transformed. In the UK, the responsibility of the state to provide and manage a substantial fraction of the housing stock has been repudiated (Lund 2004). The drive to create a population of homeowners has become a sine qua non of housing policy, at times going beyond the purchasing capacity of owners themselves. In such circumstances, not only are younger cohorts expected to play a full role in the housing market by getting established on the 'property ladder', but also the costs and strategies needed to accomplish this have led to all sorts of intergenerational compromises including more young adults returning to the parental home.

\section{New inequalities?}

Bryan Turner (1989: 603) argued that as a consequence of the post-war redistribution of income and wealth across the lifecourse, achieved in good part by the welfare state, the vertical divisions of class have been replaced by new intergenerational inequalities that may lead to a "politics of resentment' between different age groups. Our argument is that, despite the continuing growth of intergenerational inequalities, such political conflicts have not occurred nor, we contend, are they likely to occur. Not only do different cohorts share a common engagement with consumer culture, but the incomes of past and present workers are inextricably intertwined rather than being independent. The savings and investments that will fund pensions during the 2ist century derive from both the recipients' lifetime earnings and payments by younger workers today and over the coming decades. The burden represented by the latter had until recently been offset by the returns to investment of the former - returns which at times had seemed so great that they enabled employers to relieve their own responsibilities and take 'pension holidays', sometimes for years at a time (Clark 2006).

Wages in Europe have continued to rise over the last 30 years, with the result that successive cohorts of young adults have seen their average income exceed that of their immediate predecessors. In the UK, pensioner income has risen at an even faster rate (Jones et al. 2008), and other European Union countries have experienced similar increases (Organisation for Economic Cooperation and Development 200I). So long as each cohort of workers and pensioners continued to prosper, even if at different rates, the conflicts predicted by theorists of intergenerational inequality have not 
materialised. As we and others have pointed out, one consequence of the growing retiree income and wealth has been a higher real value of aggregate transfers 'down the generations' in recent decades than was possible in the earlier 2oth century when income and assets were less (Attias-Donfut 2000; Gilleard and Higgs 2005; Kohli 2004; Kohli and Albertini 2009). Increasing personal equity has resulted in greater resources for more families as more people inherit the unearned wealth of parental property (Lloyd 2008).

Over the last 20 years, paradoxically, intragenerational inequalities in the UK rather than shrinking have increased significantly (Sefton, Hills and Sutherland 2009). Such inequalities will affect younger cohorts more than those that retired at the beginning of the 2ist century, but today's young adults seem less exercised by inequalities than were their parents or grandparents. Despite the growth in inequality, the routes through which it arises have become less easily discerned. Borrowing Furlong and Cartmel's (1997) metaphor, in the past social destinations could be seen as being reached by mainline trains running along pre-determined tracks, but contemporary destinations are reached by different vehicles each negotiating their own way along an increasingly complex transport network to reach diverse final destinations. Inequalities may be greater than before, but the journey has become a more individualised experience (Beck 2007).

Contributions to and benefits from education, health and social welfare vary between and across age groups and cohorts in ways that make lines of fracture harder to detect, let alone to organise around. Health-care expenditure has risen - unevenly at times - since the ig6os. Most healthcare utilisation or consumption takes place at the beginning and end of life; contributions are greatest during the stages of life when needs are lowest. Whether funded through general taxation or through mandatory contributions, so long as health-care expenditure grows, each cohort of babies and each cohort of octogenarians will remain beneficiaries with growing 'user' expectations. Likewise, as more of those aged I6-22 years are expected to continue to learn rather than start work, the more limited educational experiences of earlier cohorts are unlikely to form a basis for conflicts over resources.

In short, increases in average household incomes, greater access to educational opportunities, and widespread consumption of health care as well as welfare entitlements signify a common social progress for members of all post-war cohorts. Equally, the steady expansion of the market for goods and services over the same period confirms this 'community of consumerist interests' in the public realm. Neither class nor cohort has had to confront the idea of an inherent limitation to the possibility of growth but now, of course, there are dark clouds on the horizon; they are 
not confined to the sustainability of the welfare state, but rather a general crisis has arisen that threatens the stability of all contemporary social institutions and the habitus that have been woven into them. Many of the motors of today's capitalism seem overwhelmed by the size of the demands that have ensued from their operation. Banks and insurance companies, global manufacturers and local retailers are all grappling with the financial turmoil, and amidst this renewed uncertainty, the refuge of the welfare state once more beckons, offering at least the prospect of re-articulating stability for all the different generations, but a return to the social compact of the 2oth century seems unlikely. Guarantees of income and wealth have become uncertain at all stages of life while there is less confidence in the viability of collective solutions. Choices have become more acute, but in the process they serve only to accentuate a culture of individualism that both limits scope for intragenerational solidarity while simultaneously rendering the form and loci of social conflict less predictable.

Claims that 'new' horizontal lines of fracture will arise seem specious. As the structures of modernity continue to fragment, the vast majority of the population are left in a 'vacuum that ... the various players must learn ... to explore without falling' (Beck 2007: 700). Pensioners, workers and students are all actors in this new landscape of contingency where the boundaries of age, generation and cohort seem less easily defined or contained than was the case in the 'old' modernity that first gave rise to the idea of the welfare state as a solution to systemic contradictions. For these reasons, we argue that a focus on the specifically 'generational' aspects of problems currently affecting both welfare states and the social organisation of later life is not only incorrect in its analysis but also runs the danger of turning the term into a trope where all the different meanings of the term - biological, historical and cultural - are used to 'fix' issues arising within what is now a more reflexive and contingent period of life.

\section{NOTES}

I This approach, sometimes known as Fixed Relative Position (FRP), is advocated by Myles (2002) as a way of overcoming some of the inequalities between generations created by contemporary pension arrangements which provide financial security in retirement but do so at the expense of other groups in society who may have greater needs. While the influence of such ideas might be seen in various national policies to increase the age of eligibility for State Retirement Pensions or in schemes to reduce the attractiveness of early retirement, in practice such ideas have remained confined to intellectual debate.

2 One recent review of pension reform in Germany has described the transformation as moving from 'defined benefits' to 'defined contributions' (Bonin 2009), while the complex interaction of policy, economy and lifestyle determinants of retirement in the 
USA has resulted in what has been described as a shift toward 'do it yourself' retirement (Cahill, Giandrea and Quinn 2008).

\section{References}

Albertini, M., Kohli, M. and Vogel, C. 2007. Intergenerational transfers of time and money in European families: common patterns, different regimes. Fournal of European Social Policy, I 7, 4, 319-34.

Annetts, J., Law, A., McNeish, W. and Mooney, G. 2009. Understanding Social Welfare Movements. Policy Press, Bristol, UK.

Attias-Donfut, C. 200o. Cultural and economic transfers between generations: one aspect of age integration. The Gerontologist, 40, 3, 270-2.

Auerbach, L., Kotlikoff, L. J. and Leibfritz, W. I999. Generational Accounting Around the World. University of Chicago Press, Chicago.

Bauman, Z. 2007. Liquid Times: Living in an Age of Uncertainty. Polity, Cambridge.

Beck, U. 2000. The Brave New World of Work. Polity, Cambridge.

Beck, U. 2007. Beyond class and nation: reframing social inequalities in a globalizing world. British Fournal of Sociology, 58, 4, 679-705.

Bonin, H. 2009. I5 years of pension reform in Germany: old successes and new threats. Geneva Papers on Risk and Insurance, 34, 4, 548-6o.

Cahill, K. E., Giandrea, M. D. and Quinn, M. F. 2008. A Micro-level Analysis of Recent Trends in Labour Force Participation Rates among Older Workers. Boston College Working Paper 2008o8, Center for Retirement Research, Boston College, Chestnut Hill, Massachusetts.

Carvel, J. 2007. Councils turn backs on care for older people. The Guardian, 22 November.

Chakravarty, S. and Weisman, C. I988. Consuming our children. Forbes Magazine I4, 222-32.

Chauvel, L. 2006. Générations sociales, perspectives de vie et soutenabilité du régime de protection sociale [Social generations: perspectives on the viability and sustainability of social protection]. In Palier, B., Hall, P. and Culpepper, P. (eds), La France en Mutation 1980-2005 [Changing France, 1980-2005]. Presses de la Fondation Nationale des Sciences Politiques, Paris, $157-96$.

Clark, G. 2006. The UK occupational pension system in crisis. In Pemberton, H., Thane, P. and Whiteside, N. (eds), Britain's Pension Crisis: History and Policy. Oxford University Press for The British Academy, Oxford, I45-68.

Costa, D. 1998. The Evolution of Retirement. University of Chicago Press, Chicago.

Department of Health 2007. Putting People First: A Shared Vision and Commitment to the Transformation of Adult Social Care. Department of Health, London.

Disney, R. 1996. Can We Afford to Grow Older? MIT Press, Cambridge, Massachusetts.

Esping-Andersen, G. 2002. Towards the good society, once again. In Esping-Andersen, G. (ed.), Why We Need a New Welfare State. Oxford University Press, Oxford, I-25.

Esping-Andersen, G. 2009. The Incomplete Revolution: Adapting to Women's New Roles. Polity, Cambridge.

Furlong, A. and Cartmel, F. 1997. Young People and Social Change: Individualization and Risk in Late Modernity. Open University Press, Buckingham, UK.

Giddens, A. 1994. Beyond Left and Right: The Future of Radical Politics. Polity, Cambridge.

Gilleard, C. and Higgs, P. I998. Older people as users and consumers of health care: a third age rhetoric for a fourth age reality. Ageing \& Society, I8, 2, 233-48.

Gilleard, C. and Higgs, P. 2005. Contexts of Ageing: Class, Cohort and Community. Polity, Cambridge. 
Gilleard, C. and Higgs, P. 2009. The power of silver: age and identity politics in the 2Ist century. Fournal of Aging and Social Policy, 2 I, 3, 277-95.

Gilleard, C., Hyde, M. and Higgs, P. 2007. Communication and community in the third age: the impact of internet and cell phone use on the attachment to place in later life in England. Fournal of Gerontology B: Social Sciences, 62, 4, $\mathrm{S}_{276-83}$.

Gokhale, J. and Kotlikoff, L. J. I999. Generational justice and generational accounting. In Williamson, J. B., Watts-Roy, D. and Kingson, E. R. (eds), The Generational Equity Debate. Columbia University Press, New York, 75-86.

Goldthorpe, J. and Mills, C. 2008. Trends in intergenerational class mobility in modern Britain: evidence from national surveys, 1972-2005. National Institute Economic Reviere, 205, I, 83-I00.

Harkin, J. and Huber, J. 2004. Eternal Youths: How the Babyboomers are Having their Time Again. Demos, London.

Heath, A. and Payne, C. 1999. 2oth Century Trends in Social Mobility in Britain. CREST Working Paper 7o, Department of Sociology, University of Oxford, Oxford. Available online at http://www.crest.ox.ac.uk/papers/p7o.pdf [Accessed 5 May 20Io].

Higgs, P., Hyde, M., Gilleard, C., Victor, C., Wiggins, R. and Jones, I. R. 2009. From passive to active consumers? Later life consumption in the UK from 1968-2005. Sociological Review, 57, I, I02-24.

Jones, I. R., Hyde, M., Victor, C., Wiggins, D., Gilleard, C. and Higgs, P. 20o8. Ageing in a Consumer Society: From Passive to Active Consumption in Britain. Policy Press, Bristol, UK.

Kohli, M. I999. Private and public transfers between generations: linking the family and the state. European Societies, I, 8I-IO4.

Kohli, M. 2004. Intergenerational transfers and inheritance: a comparative view. In Silverstein, M. and Schaie, K. W. (eds), Annual Review of Gerontology and Geriatrics. Volume 24, Springer, New York, 266-89.

Kohli, M. and Albertini, M. 2009. Childlessness and inter-generational transfers: what is at stake? Ageing \& Society, 29, 8, I173-83.

Kuhnle, S. I999. Survival of the European Welfare State. ARENA Working Paper 99/ı9, Oslo, Norway.

Laczko, F. and Phillipson, C. I991. Changing Work and Retirement. Open University Press, Buckingham, UK.

Lloyd, J. 2008. Navigating the Age of Inheritance. National Care Fund Working Groups Report, International Longevity Centre, London. Available online at http://www.ilcuk.org.uk/ files/pdf_pdf_92.pdf [Accessed 26 March 20Io].

Lund, B. 2004. Housing policy: coming in from the cold. In Ellison, M., Bauld, L. and Powell, M. (eds), Social Policy Review I6. Policy Press, Bristol, UK, I3-28.

Mannheim, K. 1997. The problem of generation. In Hardy, M. A. (ed.), Studying Aging and Social Change. Sage, London, 22-65.

Moffat, S. and Higgs, P. 2007. Charity or entitlement? Generational habitus and the welfare state among older people in North East England. Social Policy and Administration, 4I, $5,449^{-64}$.

Musgrave, R. 1986. Public Finance in a Democratic Society, ii, Fiscal Doctrine, Growth and Institutions. New York University Press, New York.

Myles, J. 2002. A new social contract for the elderly? In Esping-Andersen, G. (ed.), Why We Need a New Welfare State. Oxford University Press, Oxford, 130-72.

Organisation for Economic Cooperation and Development (OECD) 200I. Ageing and Income: Financial Resources and Retirement in 9 OECD Countries. OECD, Paris.

Preston, S. H. I984. Children and the elderly: divergent paths for America's dependents. Demography, 21, 4, 435-57.

Ransome, P. 2005. Work, Consumption and Culture: Affluence and Social Change in the Twenty-first Century. Sage, London. 
Sefton, T., Hills, J. and Sutherland, H. 2009. Poverty, inequality and redistribution. In Hills, J., Sefton, T. and Sutherland, H. (eds), Towards a More Equal Society: Poverty, Inequality and Policy Since 1997. Policy Press, Bristol, UK, 21-46.

Strangleman, T. 2007. The nostalgia for permanence at work? The end of work and its commentators. Sociological Review, 55, I, 8I-IO3.

Taylor-Gooby, P. 2004. New risks and social change. In Taylor-Gooby, P. (ed.), New Risks, New Welfare: The Transformation of the European Welfare State. Oxford University Press, Oxford, I-28.

Thomson, D. 1989. The welfare state and generation conflict: winners and losers. In Johnson, P., Conrad, C. and Thomson, D. (eds), Workers Versus Pensioners: Intergenerational Justice in an Ageing World. Manchester University Press, Manchester, UK, 33-56.

Turner, B. S. I989. Ageing, politics and sociological theory. British Fournal of Sociology, 4o, 4, 588-6o6.

Walker, A. 1990. The benefits of old age: age discrimination and social security. In McEwen, E. (ed.), Age: The Unrecognised Discrimination. Age Concern England, London, $5^{8-70 .}$

Walker, A. 2002. A strategy for active ageing. International Social Security Review, 55, I, I2 I-40.

Walker, A. 2009. Commentary: The emergence and application of active agency in Europe. Fournal of Aging and Social Policy, 2 I, I, 75-93.

Walker, R. and Wiseman, M. 2003. Making welfare work: UK activation policies under New Labour. International Social Security Review, 56, I, 3-29.

Willetts, D. 20io. The Pinch: How the Baby Boomers Took their Children's Future - and Why They Should Give it Back. Atlantic, London.

Williamson, J., MacNamara, T. and Howling, S. 2003. Generational equity, generational interdependence, and the framing of the debate over social security reform. Fournal of Sociology and Social Welfare, 3o, 3, 3-I4.

World Bank 1994. Averting the Old Age Crisis. Oxford University Press, Oxford.

World Health Organisation (WHO) 2002. Active Ageing: A Policy Framework. WHO, Geneva.

Zinn, J. 2004. Health, risk and uncertainty in the life course: a typology of biographical certainty constructions. Social Theory and Health, 2, 3, I99-22I.

Accepted 29 March 20Io; first published online 9 August 2010

Address for correspondence:

Paul Higgs, Division of Research Strategy,

University College London, Charles Bell House,

67-73 Riding House Street, London $\mathrm{W}_{\mathrm{IW}} \mathrm{F}_{\mathrm{EY}}$, UK.

E-mail:p.higgs@ucl.ac.uk 